\title{
ENCONTRAR UNA SONRISA
}

\section{Martí Soler}

No encuentro en el aire nada que se le parezca.

Hay toda clase de cordones, tijeras, azulejos y cazos de cocina y no quiero contar las horas que paso contando las horas.

No encuentro en ningún lado nada que se le acerque

Motores van y vienen por la calle

y no me dejan en paz alarmas y ladridos.

No encuentro el sabor de tus labios, pero tampoco me llega la lasitud necesaria para disfrutar el momento: ¿estoy frente a mis libros y no logro que me hablen?

No logro que me hables.

Virtual o no, te tengo frente a mí. ¿Te parece que te hable de madrugada? Es la pared de piedra la que parece decirme alguna cosa.

Sólo pretendo una sonrisa, no espero más que tu mirada de ojos miopes e intensos, no busco más que la posibilidad de cantar veredas.

Y buscar tu sonrisa que guardas muy adentro.

\section{MEDiOdÍA}

A partir de ahora, las nubes van cubriendo los picos y parecería que los sonidos de la calle se multiplican.

Te hablé pero no estabas. Supongo que nadie oyó el timbre del teléfono y que si lo oyeron a nadie le importó que sonara. 